\title{
Role of Foreign and Domestic Institutional Investors in Corporate Sustainability: Focusing on R\&D Investment
}

\author{
Ilhang Shin ${ }^{1}$ and Sorah Park ${ }^{2, *(1)}$ \\ 1 College of Business, Gachon University, Seongnam-si, Gyeonggi-do 13120, Korea; jayshih00@gachon.ac.kr \\ 2 Ewha School of Business, Ewha Womans University, Seoul 03760, Korea \\ * Correspondence: sorah.park@ewha.ac.kr
}

Received: 7 September 2020; Accepted: 19 October 2020; Published: 21 October 2020

check for updates

\begin{abstract}
This paper examines the effects of ownership by foreign and domestic institutional investors on corporate sustainability by focusing on the level of research and development (R\&D) investment. Long-term investment in R\&D is crucial for companies that seek to generate sustainable growth. Ordinary least-squares regression is performed on a sample of Korean listed companies. The main test with both foreign and domestic institutional ownership is based on a study period from 2001 to 2004 . The results indicate that firms with higher levels of foreign institutional ownership exhibit greater levels of corporate R\&D activities, while the ownership by domestic institutions has no significant influence on firms' R\&D investment. An additional test with foreign institutional ownership data is based on an extended study period from 2001 to 2014, and shows that foreign institutional ownership is positively related to firms' R\&D investment. This result survives the two-stage instrumental variable approach used to address endogeneity factors in foreign institutional ownership. Taken together, these findings suggest that foreign institutions can effectively monitor managerial myopia and promote corporate innovations.
\end{abstract}

Keywords: institutional investors; foreign institutions; domestic institutions; R\&D; innovation; sustainability

\section{Introduction}

This paper examines the role of foreign and domestic institutional investors in corporate sustainability by focusing on corporate R\&D investment. Developing corporate sustainability requires major changes to products, services, marketing strategies, and business models to develop more efficient approaches to resource and energy management [1]. Among all of these initiatives, innovative activities are key to the provision of alternative goods and services that can help with responses to climate change and ecosystem degradation [2]. In addition, only by developing innovative products that can create new demands and revenues, companies are able to generate environments that will ensure sustainable growth. Likewise, prior research [3] argues that product growth and sustainable economic growth depend on the pace of innovation. Hence, such innovation is crucial for companies' sustainable growth, gaining them competitive advantage in their products, technologies, and services [4].

For this reason, this paper focuses on corporate innovative activities that are closely linked to sustainability. Firms invest in intangible assets such as R\&D in order to gain a competitive advantage in their industries and capital markets [5]. Investments in R\&D generate new products and new information and enhance companies' ability to exploit existing information [6]. R\&D projects represent long-term strategic investments that entail higher risk, have uncertain outcomes, and they may not immediately result in positive short-term financial outcomes [7]. 
There are various determinants of the level of $R \& D$ investment. Managers tend to under-invest in risky projects, including $R \& D$ initiatives, due to their risk aversion and managerial myopia $[8,9]$. Thus, there are agency costs due to conflicts of interest between managers and shareholders. Previous studies have examined how certain corporate governance mechanisms can mitigate this agency problem and encourage managers' risk taking. For example, institutional investors have been shown to monitor myopic managers. Shleifer and Vishny [10] documented that institutional ownership is positively related to monitoring incentives, suggesting that institutional investors may encourage long-term investment in R\&D. Baysinger and Kosnik [11] provide consistent empirical evidence that concentrations of equity among institutional investors positively affect corporate R\&D spending. In addition, Bushee [12] finds that managers are less likely to cut R\&D to reverse an earnings decline when institutional ownership is high; however, when institutional investors with high portfolio turnover and momentum trading have extremely high levels of ownership, the probability that managers reduce $R \& D$ increases. Scott [13] documents that the presence of institutional investors encourages the management of firms with high information asymmetry to make long-term investments in R\&D. Moreover, Bena and Ferreira [14] show that greater foreign institutional ownership is related to greater long-term investment in tangible, intangible, and human capital, and leads to significant increases in innovation output, using a sample of publicly listed firms in 30 countries over the period 2001-2010.

Institutional investors with different geographic origins may have different monitoring incentives. Aggarwal and Erel [15] show that institutions based in non-U.S. countries with strong protections for minority shareholder rights improve firm-level governance, and those from countries with weak shareholder rights do not improve such governance. Following prior findings that foreign investors play a predominant role in the improvement of governance by non-U.S. corporations, this research posits that foreign institutions have a positive impact on corporate R\&D investment, but domestic institutions have no significant impact on R\&D investment.

This empirical study investigates the effects of foreign and domestic institutional ownership on R\&D investment using a sample of firms listed on the Korean Stock Exchange. The main test with both foreign and domestic institutional ownership is based on a sample period from 2001 to 2004, during which domestic institutional investor data were disclosed by companies in Korea. However, the study period for the analysis of foreign institutions alone is extended from 2001 to 2014, which is the last year when foreign institutional investor data is available. Ordinary least squares regression analyses of these data produce the following results. First, firms with higher levels of foreign institutional ownership have greater levels of innovative activities. However, domestic institutional ownership has no significant influence on firms' R\&D investments. Additionally, the effects of institutional ownership on R\&D remain significant after controlling for the effects of domestic ownership. Moreover, robustness tests that address endogeneity in institutional ownership based on two-stage regression provide consistent results. Collectively, the results suggest that foreign institutional investors are better at monitoring managerial incentives to undertake innovative activities than domestic ones are.

The remainder of the paper proceeds as follows. Section 2 reviews the literature on institutional investors and corporate investment in R\&D and develops research hypotheses. Section 3 describes the empirical methods used in this study, such as sampling procedures, variable measurement, and research models. Section 4 presents the results of the main tests and robustness checks performed, and finally Section 5 concludes the paper.

\section{Literature Review and Hypotheses}

Agency theorists $[8,9,16]$ argue that managers and shareholders exhibit conflicts of interest due to their different risk attitudes and incentive structures. Because executive compensation and job security usually depend upon the performance reported in financial statements and stock prices [17,18], managers may forgo risky investment projects that may harm short-term performance in order to secure their position and compensation. Prior research $[12,19,20]$ has provided evidence that managers 
are likely to underinvest in long-term projects such as $R \& D$ and employee training to ensure that short-term earnings targets are met. As a result, there are agency costs due to manager underinvestment in risky projects with positive net present value.

It has been documented that corporate governance is crucial for mitigating managerial myopia. Ownership structure is a widely documented determinant of managers' investment decisions. For instance, Eisenmann [21] showed that CEO equity ownership is positively related to risk-taking in corporate diversification. Hill and Snell [22] reported test results derived from Fortune 500 firms showing that ownership positively affects firms' attitudes toward diversification and R\&D investment. Kim and Lu [23] also document that the relation between CEO ownership and R\&D is hump shaped when external governance is weak, but is insignificant when external governance is strong. However, Wright and Kroll [24] found that value-maximizing and risky corporate strategies are initially pursued but are replaced by non-value-maximizing, risk-reducing strategies as executive stock ownership increases. Furthermore, King and Wen [25] examine the relation between overall corporate governance structure and managerial risk-taking behavior. They find that weak shareholder governance motivates more high-risk investment such as R\&D expenditures, whereas strong bondholder governance leads to lower R\&D investment.

Furthermore, according to the stakeholder theory [26], there is a positive association between effective corporate governance and corporate sustainability or corporate social responsibility (CSR) [27]. Specifically, institutional investors are documented to have a significant impact on corporate governance with their voting rights [28]. Previous studies [29-32] show that institutional investors' ownership is positively related to companies' involvement in CSR or environmental management. Moreover, recent research such as $[33,34]$ suggests that long-term institutional investors have incentives to monitor management to engage in more vigorous CSR activities.

This paper extends the literature on the relationship between institutional investors and long-term investment. On the one hand, researchers argue that institutional investors have greater incentives and more ability to monitor management. This may result in greater levels of risk-taking in corporate investment. In particular, previous studies have focused on institutional ownership as a mechanism of corporate governance or monitoring [10]. Empirical research [11,35] has provided consistent results showing that institutional ownership is positively related to managerial investment in R\&D. On the other hand, other studies have found no significant association between institutional ownership and R\&D investment [36]. This mixed evidence on the relationship between institutional ownership and $R \& D$ may be due to varying incentives of different groups of institutional investors. In other words, clearer implication on the role of institutional investors in corporate innovation could be made by distinguishing groups of institutional investors based on their incentives or abilities to monitor managerial decisions.

These arguments lead us to group institutional investors by geographical origin to examine their monitoring incentives. It has been suggested that foreign and domestic institutions have different investment horizons and monitoring incentives [15,37,38]. For example, Aggarwal and Erel [15] found that firms with greater institutional ownership tend to terminate poorly performing CEOs and improve their valuation over time. Foreign institutional investors from countries with strong shareholder protections in particular are shown to improve corporate governance of companies outside the U.S. However, ownership by domestic investors is negatively associated with improvements in corporate governance, particularly in countries with weak shareholder protections [15]. In addition, Ferreira and Matos [39] found that foreign and domestic institutions diverge in their stock preferences, in that foreign institutions prefer stocks that are cross-listed on a U.S. exchange and on the Morgan Stanley Capital International All Country World Index (MSCI ACWI). They also showed that firms with greater foreign ownership have higher valuations and better operating performance. Their findings suggest that foreign institutions support corporate monitoring worldwide because they have fewer business ties to firms and are freer from management influence than other institutions. Likewise, research using Korean data [40] has documented that domestic institutional investors often have 
business ties to local firms and are therefore more favorably disposed to top management. Hence, the close relationships between domestic institutions and top management could weaken the effective monitoring of managerial behavior.

Due to these features of foreign and domestic institutions, the effects of foreign institutional investors on managerial behavior may be distinct from those of domestic institutional investors. Specifically, foreign institutional ownership is predicted to be positively related to long-term investment in $R \& D$ projects because foreign institutional investors' monitoring may mitigate myopic managerial behavior. On the other hand, domestic institutional investors are not predicted to be positively related to R\&D investment. This is because domestic institutions' conflicts of interest may strengthen managerial myopia such that managers can reduce the level of innovation to meet short-term goals. Taken together, these considerations lead to the following hypotheses:

Hypothesis 1 (H1). Foreign institutional ownership positively affects RED investment.

Hypothesis 2 (H2). Domestic institutional ownership does not positively affect RED investment.

\section{Research Model}

\subsection{Sample Selection}

This study is based on a sample of public companies listed on the Korean Stock Exchange. Because domestic institutional investor data was disclosed by companies until 2004, the analysis of domestic institutional investors is based on a sample period beginning in 2001 and ending in 2004. However, the analysis on foreign institutional ownership covers the longer sample period from 2001 to 2014, the last year in which foreign institutional investor data is available.

Institutional investors' ownership data is matched with next year's R\&D expenditure to mitigate endogeneity concerns. The required financial data for calculating the test variables is collected from the KIS value database, provided by the NICE Information Service Co. In addition, the following sampling restrictions are imposed to ensure homogeneity in the sample: delete firms in financial industries and firms with a non-December fiscal year-end, and remove delisted firms and firms with impaired capital.

These sampling procedures result in a total of 7655 firm-year observations, consisting of 5913 observations with foreign institutional ownership over 15-year study period and 1742 observations with domestic institutional ownership over 5-year study period.

\subsection{Regression Model}

The following multivariate regression model is estimated to examine the hypotheses:

$$
\begin{aligned}
R D_{-} T O T_{i t}=\beta_{0} & +\beta_{1} F O R(\text { or DOMESTIC })_{i t}+\beta_{2} P P E_{i t}+\beta_{3} \text { SIZE }_{i t}+\beta_{4} R O A_{i t} \\
& +\beta_{5} L E V_{i t}+\beta_{6} H E R F_{i t}+\beta_{7} C A P E X_{i t}+\beta_{8} L N A G E_{i t}+\beta_{9} B T M_{i t} \\
& +\beta_{10} \text { VOL_Sales } i t+\beta_{11} \text { DIVIDEND } i t+\Sigma I N D+\Sigma Y R+\varepsilon_{i t}
\end{aligned}
$$

where 
$R D \_T O T=$ total research and development expenditure divided by the total assets at the end of year $t$; $F O R=$ proportion of foreign investors' ownership at the beginning of year $t$; DOMESTIC $=$ proportion of domestic institutional investors' ownership at the beginning of year $t$; $P P E=$ ratio of net property, plant, and equipment to the beginning total assets at the beginning of year $t$; $S I Z E=$ natural logarithm of total assets at the beginning of year $t$; $R O A=$ return on assets, calculated as the income before extraordinary items during year $t-1$, divided by total assets at the beginning of year $t$;

$L E V=$ leverage ratio, measured as the sum of long-term debts and short-term debts scaled by total assets at the beginning of year $t$;

$H E R F=$ Herfindahl index of three-digit SIC (Standard Industrial Classification) code industry $j$ to which firm $i$ belongs, measured at the beginning of fiscal year $t$;

$C A P E X=$ capital expenditure scaled by book value of total assets at the beginning of fiscal year $t$;

$L N A G E=$ natural logarithm of $(1+$ a firm's age $)$ at the beginning of fiscal year $t$;

$B T M=$ book-to-market ratio, defined as book value of equity to market value of equity, at the beginning of year $t$ $V O L \_S a l e s=$ volatility of sales using rolling five-year windows at the beginning of year $t$;

DIVIDEND = dividend yield ratio, computed as the amount of dividend payment to stock price at the beginning of year $t$;

$\sum I N D=$ industry dummies;

$\sum Y R=$ year dummies;

$\varepsilon=$ error term; and

$i, t=$ firm $i$, period $t$.

In Equation (1), the dependent variable is $R D_{-} T O T_{i t}$, representing is the total amount of a firm's $R \& D$ expenditure. $R \& D$ expenditure is selected to proxy for corporate sustainability because it is the core business activity that supports the innovations that are crucial for firms' long-term growth and sustainability. The key independent variables are equity ownership by foreign and domestic institutional investors, FOR and DOMESTIC, respectively. This captures the effects of these institutional investors on managerial decision-making in regard to innovations.

Several control variables are included in Equation (1). The model includes fixed asset intensity (PPE), firm size (SIZE), profitability $(R O A)$, leverage (LEV), investment in fixed assets (CAPEX), firm age (LNAGE), growth opportunities (BTM), volatility (VOL_Sales), and dividend-paying tendency (DIVIDEND) to control for firm characteristics that may affect corporate innovation activities. Product market competition (HERF), which is measured by the Herfindahl index based on annual sales, is included to control for industry characteristics. Last, industry and year fixed effects are included in the regression models, and standard errors are corrected for heteroscedasticity.

\section{Results of the Empirical Analysis}

\subsection{Descriptive Statistics and Correlation Analysis}

Table 1 shows the descriptive statistics of the variables used in this study. The mean value for total $R \& D$ expenditure (scaled by total assets) is 1.1770 , and the median is 0.2655 . This indicates a skewed distribution, suggesting that few companies have significantly larger amounts of R\&D spending than the rest. On average, foreign institutions and domestic institutions own $9.72 \%$ and $8.19 \%$ of the equity shares of sample firms, respectively. Moreover, the sample firms have an average firm size of 25.23, ROA of $3.13 \%$, leverage ratio of $45 \%$, and fixed asset intensity of $35 \%$. Last, overall observation indicates that the test variables and continuous control variables are mostly normally distributed. 
Table 1. Descriptive Statistics.

\begin{tabular}{ccccccc}
\hline Variable & $\boldsymbol{N}$ & Mean & Std Dev & Median & $\mathbf{2 5 \%}$ & $\mathbf{7 5 \%}$ \\
\hline RD_TOT & 7655 & 1.1770 & 1.9950 & 0.2655 & 0.0000 & 1.4495 \\
FOR & 7655 & 0.0972 & 0.1413 & 0.0296 & 0.0030 & 0.1351 \\
DOMESTIC & 1742 & 0.0819 & 0.1197 & 0.0350 & 0.0040 & 0.1116 \\
PPE & 7655 & 0.3512 & 0.2045 & 0.3414 & 0.2040 & 0.4787 \\
SIZE & 7655 & 25.5370 & 1.7687 & 25.2205 & 24.2742 & 26.4810 \\
ROA & 7655 & 0.0313 & 0.0885 & 0.0348 & 0.0061 & 0.0729 \\
LEVERAGE & 7655 & 0.4517 & 0.2058 & 0.4494 & 0.2976 & 0.5935 \\
HERF & 7655 & 0.1267 & 0.1308 & 0.0731 & 0.0347 & 0.1731 \\
CAPEX & 7655 & 0.2179 & 0.2700 & 0.1266 & 0.0610 & 0.2606 \\
LNAGE & 7655 & 3.5171 & 0.5253 & 3.6109 & 3.3322 & 3.8501 \\
BTM & 7655 & 1.8401 & 8.4404 & 1.3525 & 0.7850 & 2.2516 \\
VOL_Sales & 7655 & 0.2233 & 0.8036 & 0.1394 & 0.0778 & 0.2377 \\
DIVIDEND & 7655 & 0.7152 & 0.4513 & 1.0000 & 0.0000 & 1.0000 \\
\hline
\end{tabular}

Note: All variables are defined in Equation (1). All $p$-values are based on two-tailed $t$-tests.

Table 2 reports the Pearson correlation coefficients among the test variables. RD_TOT is positively correlated with foreign institutional ownership but uncorrelated with domestic institutional ownership. Further, $R D \_T O T$ is positively correlated with firm size, ROA, and dividend policy, and it is negatively correlated with leverage, firm age, and book-to-market ratio. In addition, unlike prior research showing a positive association between product market competition and innovations, there is no significant correlation between HERF and RD_TOT. Overall, these analyses suggest that multivariate regression is warranted to confirm the association between R\&D and foreign (domestic) institutional ownership, controlling for these firm characteristics.

Table 2. Correlations among the Test and Control Variables.

\begin{tabular}{|c|c|c|c|c|c|c|c|c|c|c|c|c|}
\hline & FOR & DOMESTIC & $P P E$ & SIZE & $R O A$ & LEVERAGE & HERF & CAPEX & LNAGE & $B T M$ & VOL_Sales & DIVIDEND \\
\hline \multirow{2}{*}{ RD_TOT } & 0.192 & 0.011 & -0.138 & 0.193 & 0.102 & -0.098 & 0.014 & 0.030 & -0.094 & -0.029 & -0.011 & 0.076 \\
\hline & $<0.0001$ & 0.634 & $<0.0001$ & $<0.0001$ & $<0.0001$ & $<0.0001$ & 0.225 & 0.008 & $<0.0001$ & 0.010 & 0.333 & $<0.0001$ \\
\hline \multirow{2}{*}{ FOR } & & 0.070 & -0.028 & 0.568 & 0.254 & -0.146 & 0.157 & 0.045 & -0.057 & -0.049 & -0.019 & 0.237 \\
\hline & & 0.004 & 0.014 & $<0.0001$ & $<0.0001$ & $<0.0001$ & $<0.0001$ & $<0.0001$ & $<0.0001$ & $<0.0001$ & 0.091 & $<0.0001$ \\
\hline \multirow{2}{*}{ DOMESTIC } & & & 0.088 & 0.223 & 0.100 & 0.078 & 0.106 & -0.037 & 0.094 & 0.031 & 0.127 & -0.051 \\
\hline & & & 0.000 & $<0.0001$ & $<0.0001$ & 0.001 & $<0.0001$ & 0.119 & $<0.0001$ & 0.189 & $<0.0001$ & 0.033 \\
\hline \multirow{2}{*}{$P P$} & & & & -0.014 & 0.027 & 0.180 & 0.057 & -0.017 & 0.062 & 0.046 & -0.082 & 0.002 \\
\hline & & & & 0.236 & 0.017 & $<0.0001$ & $<0.0001$ & 0.128 & $<0.0001$ & $<0.0001$ & $<0.0001$ & 0.873 \\
\hline \multirow{2}{*}{ SIZE } & & & & & 0.286 & -0.117 & 0.232 & 0.005 & -0.043 & -0.096 & -0.003 & 0.271 \\
\hline & & & & & $<0.0001$ & $<0.0001$ & $<0.0001$ & 0.657 & 0.000 & $<0.0001$ & 0.803 & $<0.0001$ \\
\hline \multirow{2}{*}{$R O A$} & & & & & & -0.354 & 0.014 & 0.097 & -0.091 & 0.019 & -0.001 & 0.472 \\
\hline & & & & & & $<0.0001$ & 0.233 & $<0.0001$ & $<0.0001$ & 0.098 & 0.920 & $<0.0001$ \\
\hline \multirow{2}{*}{ LEVERAGE } & & & & & & & 0.104 & -0.073 & -0.003 & -0.035 & 0.075 & -0.384 \\
\hline & & & & & & & $<0.0001$ & $<0.0001$ & 0.818 & 0.002 & $<0.0001$ & $<0.0001$ \\
\hline \multirow{2}{*}{ HERF } & & & & & & & & 0.006 & -0.011 & -0.020 & 0.073 & -0.052 \\
\hline & & & & & & & & 0.577 & 0.345 & 0.086 & $<0.0001$ & $<0.0001$ \\
\hline \multirow{2}{*}{ CAPEX } & & & & & & & & & -0.093 & -0.014 & 0.037 & 0.045 \\
\hline & & & & & & & & & $<0.0001$ & 0.237 & 0.001 & $<0.0001$ \\
\hline \multirow{2}{*}{ LNAGE } & & & & & & & & & & 0.041 & -0.034 & -0.012 \\
\hline & & & & & & & & & & 0.000 & 0.003 & 0.293 \\
\hline \multirow{2}{*}{ BTM } & & & & & & & & & & & -0.026 & -0.016 \\
\hline & & & & & & & & & & & 0.021 & 0.171 \\
\hline \multirow{2}{*}{ VOL_Sales } & & & & & & & & & & & & -0.055 \\
\hline & & & & & & & & & & & & $<0.0001$ \\
\hline
\end{tabular}




\subsection{Results of Multivariate Analyses}

Table 3 reports the relationship between foreign institutional investors and R\&D activities in two columns for main study period (2001-2004) and extended study period (2001-2014), respectively.

Table 3. Hypothesis 1: Foreign Investors and R\&D Activities.

\begin{tabular}{ccccc}
\hline \multirow{2}{*}{ Variables } & \multicolumn{4}{c}{ Dependent Variable = RD_TOT } \\
\cline { 2 - 5 } & Study Period: 2001-2004 & Study Period: 2001-2014 \\
\cline { 2 - 5 } & Coef. & $p$-Value & Coef. & $p$-Value \\
\hline Intercept & 1.3990 & 0.0776 & -2.1080 & $<0.01$ \\
FOR & 1.6650 & $<0.01$ & 1.2711 & $<0.01$ \\
PPE & -1.4099 & $<0.01$ & -1.2796 & $<0.01$ \\
SIZE & 0.0775 & 0.0144 & 0.1744 & $<0.01$ \\
ROA & 1.6503 & $<0.01$ & 0.5139 & 0.0845 \\
LEV & -0.5846 & $<0.01$ & -0.4186 & $<0.01$ \\
HERF & -0.0335 & 0.8999 & -0.3921 & 0.0256 \\
CAPEX & -0.0936 & 0.3859 & 0.0222 & 0.7887 \\
LNAGE & -0.4205 & $<0.01$ & -0.2658 & $<0.01$ \\
BTM & -0.0240 & $<0.01$ & -0.0021 & 0.4135 \\
VOL_Sales & -0.0561 & 0.2185 & -0.0519 & 0.0602 \\
DIVIDEND & 0.0000 & 0.9154 & -0.0842 & 0.1489 \\
IND, $\Sigma Y R$ & \multicolumn{2}{c}{ Included } & \multicolumn{2}{c}{ Included } \\
Adjusted $\mathrm{R}^{2}$ & \multicolumn{2}{c}{$11.14 \%$} & \multicolumn{2}{c}{7655} \\
Sample Size & \multicolumn{2}{c}{1742} \\
\hline
\end{tabular}

Note: All variables are defined in Equation (1).

The regression coefficients for foreign institutional ownership $(F O R)$ are statistically significant and positive, $1.6650(p<0.01)$ and $1.2711(p<0.01)$, in both study periods. This suggests that firms' R\&D spending increases with foreign institutional ownership, implying that foreign institutions encourage innovative activities over a long-term investment horizon. This is consistent with prior research showing that foreign institutional investors improve corporate governance and mitigate managerial short-term orientation.

The control variables also have the expected signs. For example, $R D_{-} T O T$ is positively related to SIZE, indicating that larger firms tend to invest in R\&D projects to a greater extent. Unlike the insignificant correlations reported in Table 2, there is a significant and positive association between $H E R F$ and $R D_{-} T O T$, which implies that firms that face greater product market competition have greater levels of R\&D investment. However, $R D_{-} T O T$ is negatively associated with leverage and firm age.

Table 4 shows the results of multivariate regression for the association between domestic institutional ownership and innovation over the main study period 2001-2004.

Domestic institutional ownership has no significant relationship with R\&D investment, as the estimated coefficient for DOMESTIC is not significantly different than zero $(-0.3194, p=0.3120)$. The regression coefficients for control variables are not largely different from those reported in Table 3. This suggests that domestic institutions do not play a significant role in promoting corporate innovative activities due to their shorter-term investment horizon and business ties to the companies invested in.

Next, Table 5 shows the regression results when both foreign and domestic institutional ownership variables are included in the same model. Doing so allows us to examine incremental effects of foreign institutions after controlling for domestic institutional shareholdings. 
Table 4. Hypothesis 2: Domestic Investors and R\&D Activities.

\begin{tabular}{|c|c|c|}
\hline \multirow{2}{*}{ Variables } & \multicolumn{2}{|c|}{ Dependent Variable $=R D \_T O T$} \\
\hline & Coef. & $p$-Value \\
\hline Intercept & -2.4580 & $<0.01$ \\
\hline DOMESTIC & -0.3194 & 0.3120 \\
\hline PPE & -1.4284 & $<0.01$ \\
\hline SIZE & 0.2381 & $<0.01$ \\
\hline$R O A$ & 1.5804 & $<0.01$ \\
\hline$L E V$ & -0.3679 & 0.0774 \\
\hline HERF & -0.2625 & 0.3186 \\
\hline CAPEX & -0.1256 & 0.2417 \\
\hline LNAGE & -0.3896 & $<0.01$ \\
\hline BTM & -0.0206 & $<0.01$ \\
\hline VOL_Sales & -0.0615 & 0.1782 \\
\hline DIVIDEND & -0.0140 & 0.8835 \\
\hline$\Sigma I N D, \Sigma Y R$ & \multicolumn{2}{|c|}{ Included } \\
\hline Adjusted $\mathrm{R}^{2}$ & \multicolumn{2}{|c|}{$12.76 \%$} \\
\hline Sample Size & \multicolumn{2}{|c|}{1742} \\
\hline
\end{tabular}

Note: All variables are defined in Equation (1).

Table 5. Foreign vs. Domestic Investors and R\&D Activities.

\begin{tabular}{ccc}
\hline \multirow{2}{*}{ Variables } & \multicolumn{2}{c}{ Dependent Variable $=$ RD_TOT } \\
\cline { 2 - 3 } & Coef. & $\boldsymbol{p}$-Value \\
\hline Intercept & -1.6183 & 0.0477 \\
FOR & 0.7166 & 0.0401 \\
DOMESTIC & -0.2643 & 0.4041 \\
PPE & -1.4232 & $<0.01$ \\
SIZE & 0.2016 & $<0.01$ \\
ROA & 1.5038 & $<0.01$ \\
LEV & -0.3708 & 0.0749 \\
HERF & -0.2586 & 0.3254 \\
CAPEX & -0.1259 & 0.2398 \\
LNAGE & -0.3894 & $<0.01$ \\
BTM & -0.0193 & $<0.01$ \\
VOL_Sales & -0.0593 & 0.1936 \\
DIVIDEND & -0.0251 & 0.7928 \\
$\Sigma$ IND, $\Sigma Y R$ & \multicolumn{2}{c}{ Included } \\
\hline Adjusted $\mathrm{R}^{2}$ & \multicolumn{2}{c}{$12.92 \%$} \\
Sample Size & \multicolumn{2}{c}{1742} \\
\hline
\end{tabular}

Note: All variables are defined in Equation (1).

The results are reported in Table 5. Foreign institutional shareholdings are significantly and positively related to R\&D investment (coef. $=0.7166, p=0.0401$ ), while domestic shareholdings are not significantly related to R\&D investment (coef. $=-0.2643, p=0.4041$ ). This is consistent with the findings shown in Tables 3 and 4, thereby confirming the differential roles played by foreign and domestic institutional investors in corporate innovative activities.

\subsection{Robustness Check}

This section presents the results of an additional robustness check that addresses the endogeneity of foreign institutional ownership. Foreign institutional ownership is not an exogenous variable 
because foreign institutions select stocks for their portfolios based on their stock preference and investment motivation. It may be that foreign institutions prefer innovative companies that exhibit long-term growth. Hence, a two-stage instrumental variable approach is performed to mitigate potential endogeneity concerns due to reverse causality.

Prior research $[39,41]$ has shown that foreign institutional investors prefer stocks that are cross-listed on a U.S. exchange and on the MSCI All Country World Index (MSCI ACWI). While historical listing on the MSCI ACWI is positively related to foreign equity ownership, it is not related to corporate decisions such as increasing R\&D investment because MSCI ACWI listing is automatically determined by a mechanical rule based on market capitalization [14]. For this reason, a historical listing on the MSCI ACWI is selected as the instrumental variable for foreign institutional ownership.

Table 6 Panel A reports the first-stage regression results. The dependent variable, FOR, is significantly and positively associated with $M S C I$, an instrumental variable that is set to 1 if the firm is listed on the MSCI ACWI during a given year $t$ (coef. $=0.0765, p<0.01$ ). Panel B-1 of Table 6 shows second-stage regression results using the predicted value of foreign institutional ownership estimated from the first-stage model as the independent variable. The regression coefficient of instrumented FOR is significantly positive (coef. $=3.6057, p<0.01$ ). This result holds after controlling for the effect of DOMESTIC. As shown in Table 6 Panel B-2, the coefficient of instrumented FOR is significantly positive $(2.3553, p=0.0408)$, while the coefficient for DOMESTIC is not statistically significant $(-0.3149, p=0.3207)$.

The main test results and robustness checks using instrumental variables provide consistent evidence that foreign and domestic institutional investors may have different incentives for monitoring managerial myopia. Unlike domestic institutions, foreign institutions can effectively encourage long-term investment for long-term growth such as in R\&D, suggesting that foreign institutional ownership may improve corporate governance.

Table 6. Foreign Institutional Investors and R\&D Activities: Two-Stage Least-Squares Regression Analyses.

\begin{tabular}{|c|c|c|}
\hline \multicolumn{3}{|c|}{ Panel A: First-stage Regression } \\
\hline \multirow{2}{*}{ Variables } & \multicolumn{2}{|c|}{ Dependent Variable $=F O K$} \\
\hline & Coef. & $p$-Value \\
\hline Intercept & -0.7702 & $<0.01$ \\
\hline MSCI [Instrument] & 0.0765 & $<0.01$ \\
\hline$P P E$ & -0.0238 & 0.1845 \\
\hline SIZE & 0.0339 & $<0.01$ \\
\hline$R O A$ & 0.1138 & $<0.01$ \\
\hline$L E V$ & -0.0402 & 0.0452 \\
\hline HERF & 0.0397 & 0.2241 \\
\hline CAPEX & 0.0094 & 0.2551 \\
\hline LNAGE & -0.0041 & 0.5628 \\
\hline BTM & -0.0002 & 0.1337 \\
\hline VOL_Sales & -0.0043 & $<0.01$ \\
\hline DIVIDEND & 0.0122 & 0.1169 \\
\hline$\Sigma I N D, \Sigma Y R$ & \multicolumn{2}{|c|}{ Included } \\
\hline Adjusted $\mathrm{R}^{2}$ & \multicolumn{2}{|c|}{$37.29 \%$} \\
\hline Sample Size & \multicolumn{2}{|c|}{7655} \\
\hline
\end{tabular}

Panel B: Second-stage Regression-Foreign and Domestic Investors 
Table 6. Cont.

\begin{tabular}{|c|c|c|c|c|}
\hline \multirow{3}{*}{ Variables } & \multicolumn{4}{|c|}{ Dependent Variable $=R D \_T O T$} \\
\hline & \multicolumn{2}{|c|}{ Study Period: 2001-2004 } & \multicolumn{2}{|c|}{ Study Period: 2001-2014 } \\
\hline & Coef. & $p$-Value & Coef. & $p$-Value \\
\hline Intercept & -0.3776 & 0.7648 & 0.3548 & 0.6833 \\
\hline FOR [Predicted] & 2.3553 & 0.0408 & 3.6057 & $<0.01$ \\
\hline DOMESTIC & -0.3149 & 0.3207 & & \\
\hline PPE & -1.3294 & $<0.01$ & -1.2181 & $<0.01$ \\
\hline SIZE & 0.1337 & 0.0146 & 0.0717 & 0.0499 \\
\hline$R O A$ & 1.7778 & $<0.01$ & 0.7608 & 0.0120 \\
\hline$L E V$ & -0.1707 & 0.4296 & -0.3391 & $<0.01$ \\
\hline HERF & -0.3361 & 0.2078 & -0.5002 & $<0.01$ \\
\hline CAPEX & -0.1610 & 0.1344 & -0.0069 & 0.9343 \\
\hline$L N A G E$ & -0.3428 & $<0.01$ & -0.2739 & $<0.01$ \\
\hline BTM & -0.0207 & $<0.01$ & -0.0035 & 0.2727 \\
\hline VOL_Sales & -0.0490 & 0.2833 & -0.0361 & 0.1944 \\
\hline DIVIDEND & -0.0137 & 0.8887 & -0.1275 & 0.0338 \\
\hline$\Sigma I N D, \Sigma Y R$ & \multicolumn{2}{|c|}{ Included } & \multicolumn{2}{|c|}{ Included } \\
\hline Adjusted $\mathrm{R}^{2}$ & \multicolumn{2}{|c|}{$12.34 \%$} & \multicolumn{2}{|c|}{$7.84 \%$} \\
\hline Sample Size & \multicolumn{2}{|c|}{1742} & \multicolumn{2}{|c|}{7655} \\
\hline
\end{tabular}

Note: $M S C I$ is an instrumental variable that is set to 1 if the firm is listed on the MSCI ACWI during a given year $t$. All other variables are defined in Equation (1).

\section{Discussion}

Prior research indicates that domestic and foreign institutional investors play different roles in influencing managerial behavior $[15,37,38]$. This may be because foreign institutions have fewer business ties to local companies and are freer from management influence than other institutional investors are $[15,37]$. Domestic institutional investors, on the other hand, often have business ties to local firms or have potential conflicts of interest due to their close relationships with top management in the firms they invest in [40].

This research adds new evidence to the literature by documenting the distinct monitoring behavior performed by foreign and domestic institutional investors for managerial investment in R\&D, which is essential for long-term growth and corporate sustainability. Foreign institutions perform effective monitoring of managerial incentives to undertake long-term intangible projects, while domestic institutions do not encourage long-term corporate investment in terms of corporate sustainability.

These findings suggest that institutional investors may not serve as an effective corporate governance mechanism due to business ties in emerging markets. In Korea, large business groups (so called chaebols) grew rapidly with support by banks and government. Like other emerging economies, banks have been important institutional investors in Korea and they have business ties to chaebol groups to some extent. Due to due to the business ties between institutions and chaebol groups, institutional investors tend to maximize the wealth of owners of chaebols, rather than maximizing shareholder value.

One example of anecdotal evidence showing that institutional investors maximize the wealth of chaebol owners rather than shareholders is the merger of Samsung C\&T (the parent company of Samsung Group) and Cheil Industries in 2015. When the merger plan was announced, some shareholders of Samsung C\&T including Elliott Management Corporation, an U.S. hedge fund, opposed the proposed merger because the deal was unfair. In addition, the Institutional Shareholder Service (ISS) and the Korea Corporate Governance Service recommended that shareholders of Samsung C\&T vote against the merger plan. However, the National Pension Service, a domestic institutional investor and the second largest shareholder of Samsung C\&T, decided to vote for the merger plan. In fact, most of domestic institutional investors voted for the plan. As a result, the merger plan was approved at the 
general shareholder meeting of Cheil and Samsung C\&T. This case shows the crucial role of institutional investors in protecting shareholders' interests and agency problem between controlling and minority shareholders [42].

Moreover, this particular case drew public attention to the need for the stewardship code defining the norm of conduct of institutional investors as shareholder activists so that institutional investors promote long-term firm value and corporate sustainability. In 2018, in response to this need, the National Pension Service, which is the largest domestic institutional investor in Korea, implemented the stewardship code which specifies that they actively participate in decision-making of investee companies in order to achieve sustainable growth and transparent management. The Korea Stewardship Code, "Principles on Institutional Investors' Fiduciary Duties," presents seven principles and guidelines that institutional investors should implement to fulfill their fiduciary duties: establish and disclose a fiduciary responsibility policy, establish and disclose a conflicts of interest policy, periodic monitoring on investee companies, internal guidelines on stewardship activities, establish and disclose a voting policy and voting records, periodic reporting of voting and stewardship activities, and build up capabilities and expertise.

Since the introduction of the stewardship code, the rate of National Pension Service opposition to management decisions has increased, and this trend is expected to strengthen in the future. The best example of the use of the stewardship code is the rejection of the appointment of Hanjin Group's chairman, Mr. Yang-ho Cho, to an executive director position in 2019. The reason for the rejection was that owner families have consistently acted against the sustainable growth and transparent management of the company due to mishaps such as embezzlement and tax evasion.

Therefore, the empirical test results that domestic institutional investors' ownership is not positively related to $R \& D$ investment provide a policy and practical implication in that the government needs to undertake a policy approach that enables institutional investors to care about corporate sustainability and encourage long-term investments in R\&D.

\section{Conclusions}

This paper examines how institutional investors affect corporate sustainability by promoting long-term intangible investment. The main tests are based on the multivariate regression analyses on a set of control variables that appeared to be related to the dependent variable (i.e., R\&D investment), such as firm size, fixed-asset intensity, profitability, and industry competition. When foreign institutional ownership was used as the main test variable, there was a positive association between foreign institutional ownership and R\&D spending. However, when domestic institutional ownership was included, there was no significant relationship between the test variable and the dependent variable. Furthermore, additional analysis includes both foreign and domestic institutional ownership variables in the regression model to test their incremental explanatory power. Moreover, two-stage least squares regression is employed to address the endogeneity of foreign institutional ownership by using historical listing on the MSCI ACWI as an instrumental variable. A battery of additional tests produced consistent evidence that foreign ownership is positively related to R\&D investment, but domestic ownership is not.

The results of this study show that foreign and domestic institutional investors play different roles in investment in long-term intangibles and consequently differentially affect corporate sustainability. This study extends the existing literature on the role that institutional investors play in governance in the contemporary global economy by considering both foreign and domestic institutions and determining which group makes a greater contribution to corporate innovations. Specifically, given the importance of foreign institutions in emerging markets, the effectiveness of their monitoring and their impacts on corporate sustainability are worth studying.

In addition, this paper adds to prior research on how corporate innovations are affected by various corporate governance mechanisms. For example, executive incentive compensation is one of governance mechanisms that can be used to promote managers' innovative activities. Additionally, 
various stakeholders could play crucial roles in innovations. For instance, Shin and Park [43] shed light on the effect of labor unions on corporate innovations and their market valuation. The current research extends the line of research by examining the role of investors with blockholdings who have incentives to engage in long-term governance.

However, this study is not without limitations. The comparison between foreign and domestic institutional investors may be subject to criticism due to the relatively short sample period that was forced to be used, as domestic institutional investor data are only available up to 2004. Hence, future studies may examine the role of domestic institutional investors in corporate innovation using more recent data and using a longer sample period, if available.

Author Contributions: Methodology, I.S.; formal analysis, I.S.; writing-original draft preparation, S.P.; writing-review and editing, S.P. All authors have read and agreed to the published version of the manuscript.

Funding: This research received no external funding.

Conflicts of Interest: The authors declare no conflict of interest.

\section{References}

1. Seebode, D.; Jeanrenaud, S.; Bessant, J. Managing innovation for sustainability. RD Manag. 2012, 42, $195-206$. [CrossRef]

2. Lehni, M. Eco-Efficiency. Creating More Value with Less Impact; WBCSD: Conches-Geneva, Switzerland, 2000.

3. Gordon, R.J. Five Puzzles in the Behavior of Productivity, Investment, and Innovation; National Bureau of Economic Research: Cambridge, MA, USA, 2004.

4. Balkin, D.B.; Markman, G.D.; Gomez-Mejia, L.R. Is CEO pay in high-technology firms related to innovation? Acad. Manag. J. 2000, 43, 1118-1129. [CrossRef]

5. Lev, B. Intangibles: Management, Measurement, and Reporting; Brookings Institution Press: Washington, DC, USA, 2000.

6. Cohen, W.M.; Levinthal, D.A. Absorptive capacity: A new perspective on learning and innovation. Admin. Sci. Quart. 1990, 128-152. [CrossRef]

7. Hoskisson, R.E.; Hitt, M.A.; Hill, C.W. Managerial incentives and investment in R\&D in large multiproduct firms. Organ. Sci. 1993, 4, 325-341.

8. Jensen, M.C.; Meckling, W.H. Agency costs and the theory of the firm. J. Fin. Econ. 1976, 3, 305-360. [CrossRef]

9. Amihud, Y.; Lev, B. Risk reduction as a managerial motive for conglomerate mergers. Bell. J. Econ. 1981, 605-617. [CrossRef]

10. Shleifer, A.; Vishny, R.W. Large shareholders and corporate control. J. Pol. Econ. 1986, 94, 461-488. [CrossRef]

11. Baysinger, B.D.; Kosnik, R.D.; Turk, T.A. Effects of board and ownership structure on corporate R\&D strategy. Acad. Manag. J. 1991, 34, 205-214.

12. Bushee, B.J. The influence of institutional investors on myopic R\&D investment behavior. Acc. Rev. 1998, 305-333.

13. Scott, R.W. Do institutional investors influence R\&D investment policy in firms with high information asymmetry? Int. Bus. Res. 2014, 7, 22-35.

14. Bena, J.; Ferreira, M.A.; Matos, P.; Pires, P. Are foreign investors locusts? The long-term effects of foreign institutional ownership. J. Fin. Econ. 2017, 126, 122-146. [CrossRef]

15. Aggarwal, R.; Erel, I.; Ferreira, M.; Matos, P. Does governance travel around the world? Evidence from institutional investors. J. Fin. Econ. 2011, 100, 154-181. [CrossRef]

16. Fama, E.F.; Jensen, M.C. Separation of ownership and control. J. Law. Econ. 1983, 26, 301-325. [CrossRef]

17. Cheng, S. R\&D expenditures and CEO compensation. Account. Rev. 2004, 79, 305-328.

18. Dechow, P.M.; Skinner, D.J. Earnings management: Reconciling the views of accounting academics, practitioners, and regulators. Account. Hor. 2000, 14, 235-250. [CrossRef]

19. Dechow, P.M.; Sloan, R.G. Executive incentives and the horizon problem: An empirical investigation. J. Account. Econ. 1991, 14, 51-89. [CrossRef]

20. Asker, J.; Farre-Mensa, J.; Ljungqvist, A. Corporate investment and stock market listing: A puzzle? Rev. Fin. Stud. 2015, 28, 342-390. [CrossRef] 
21. Eisenmann, T.R. The effects of CEO equity ownership and firm diversification on risk taking. Strat. Manag. J. 2002, 23, 513-534. [CrossRef]

22. Hill, C.W.; Snell, S.A. Effects of ownership structure and control on corporate productivity. Acad. Manag. J. 1989, 32, 25-46.

23. Kim, E.H.; Lu, Y. CEO ownership, external governance, and risk-taking. J. Fin. Econ. 2011, 102, $272-292$. [CrossRef]

24. Wright, P.; Kroll, M.; Lado, A.; Van Ness, B. The structure of ownership and corporate acquisition strategies. Strat. Manag. J. 2002, 23, 41-53. [CrossRef]

25. King, T.-H.D.; Wen, M.-M. Shareholder governance, bondholder governance, and managerial risk-taking. J. Bank. Fin. 2011, 35, 512-531. [CrossRef]

26. Letza, S.; Sun, X.; Kirkbride, J. Shareholding versus stakeholding: A critical review of corporate governance. Corp. Gov. Int. Rev. 2004, 12, 242-262. [CrossRef]

27. Prado-Lorenzo, J.-M.; Garcia-Sanchez, I.-M. The role of the board of directors in disseminating relevant information on greenhouse gases. J. Bus. Ethics 2010, 97, 391-424. [CrossRef]

28. Shleifer, A.; Vishny, R.W. A survey of corporate governance. J. Fin. 1997, 52, 737-783. [CrossRef]

29. Eskeland, G.A.; Harrison, A.E. Moving to Greener Pastures? Multinationals and the Pollution Haven Hypothesis; National Bureau of Economic Research: Cambridge, MA, USA, 2002.

30. Oh, W.Y.; Chang, Y.K.; Martynov, A. The effect of ownership structure on corporate social responsibility: Empirical evidence from Korea. J. Bus. Ethics 2011, 104, 283-297. [CrossRef]

31. Cox, P.; Brammer, S.; Millington, A. An empirical examination of institutional investor preferences for corporate social performance. J. Bus. Ethics 2004, 52, 27-43. [CrossRef]

32. Neubaum, D.O.; Zahra, S.A. Institutional ownership and corporate social performance: The moderating effects of investment horizon, activism, and coordination. J. Manag. 2006, 32, 108-131. [CrossRef]

33. Kim, H.D.; Kim, T.; Kim, Y.; Park, K. Do long-term institutional investors promote corporate social responsibility activities? J. Bank. Fin. 2019, 101, 256-269. [CrossRef]

34. Gloßner, S. Investor horizons, long-term blockholders, and corporate social responsibility. J. Bank. Fin. 2019, 103, 78-97. [CrossRef]

35. Kochhar, R.; David, P. Institutional investors and firm innovation: A test of competing hypotheses. Strat. Manag. J. 1996, 17, 73-84. [CrossRef]

36. Chung, K.H.; Wright, P.; Kedia, B. Corporate governance and market valuation of capital and R\&D investments. Rev. Fin. Econ. 2003, 12, 161-172.

37. Ferreira, M.A.; Massa, M.; Matos, P. Shareholders at the gate? Institutional investors and cross-border mergers and acquisitions. Rev. Fin. Stud. 2010, 23, 601-644. [CrossRef]

38. Stulz, R.M. The limits of financial globalization. J. Fin. 2005, 60, 1595-1638. [CrossRef]

39. Ferreira, M.A.; Matos, P. The colors of investors' money: The role of institutional investors around the world. J. Fin. Econ. 2008, 88, 499-533. [CrossRef]

40. Choi, J.J.; Park, S.W.; Yoo, S.S. The value of outside directors: Evidence from corporate governance reform in Korea. J. Fin. Quant. Analy. 2007, 42, 941-962. [CrossRef]

41. Cremers, M.; Ferreira, M.A.; Matos, P.; Starks, L. Indexing and active fund management: International evidence. J. Fin. Econ. 2016, 120, 539-560. [CrossRef]

42. Kim, B.J.; Lee, M. Merger between Cheil Industries and Samsung C\&T: Revisited. Korean Account. J. 2017, 26, 337-369.

43. Shin, I.; Park, S.; Cho, S.P.; Choi, S. The effect of labor unions on innovation and market valuation in business group affiliations: New evidence from South Korea. Asian Bus. Manag. 2020, 19, 239-270. [CrossRef]

Publisher's Note: MDPI stays neutral with regard to jurisdictional claims in published maps and institutional affiliations. 